\title{
An oral vaccine against CVA16 (Coxsackievirus A16) was developed by constructing a recombinant Lactococcus lactis
}

\author{
Zaixue Jiang ${ }^{1}$, Xingui Tian², Xiaomei Lu ${ }^{1}$, Baimao Zhong ${ }^{1 *}$ \\ ${ }^{1}$ Dongguan Institute of Paediatrics, Dongguan Children's Hospital, The Eighth People's Hospital of Dongguan City, Dongguan \\ 523325, ${ }^{2}$ State Key Laboratory of Respiratory Disease, Guangzhou Institute of Respiratory Disease, The First Affiliated \\ Hospital of Guangzhou Medical University, Guangzhou 510230, China
}

*For correspondence: Email: zbm@dgp-institute.com

Sent for review: 16 January 2020

Revised accepted: 30 April 2020

\begin{abstract}
Purpose: To develop an oral vaccine against CVA16 (Coxsackievirus A16) by constructing a recombinant Lactococcus lactis that expresses VP1 from CVA16.

Method: An oral CVA16 vaccine was prepared by expressing CVA16 VP1 protein with Lactococcus lactis. CVA16 VP1 gene was incorporated into a Lactobacillus expression vector, namely, pNZ8148, and then expressed in NZ9000, a food-grade lactic acid bacterium which serves as a carrier for oral vaccines.

Results: There was statistically significant difference in CVA16-specific IgG antibody level between NZ9000-pNZ8148-CVA16-VP1 group $(0.49 \pm 0.05)$ and control group $(0.05 \pm 0.00)$ when the antiserum was diluted 1:10 ( $t=19.84 ; p<0.05)$. Furthermore, the level of CVA16-specific IgA antibody in NZ9000pNZ8148-CVA16-VP1 group $(0.17 \pm 0.02)$ was significantly higher than in control group $(0.05 \pm 0.00)$ following antiserum dilution of 1:10 $(t=12.08 ; p<0.05)$.

Conclusion: A CVA16 oral vaccine made from Lactobacillus elicits protective antibodies against CVA16. Thus, it is a potential as oral vaccine against CVA16 but further studies in vivo are required to ascertain its safety and effectiveness.
\end{abstract}

Keywords: Coxsackievirus A16, Hand, foot and mouth disease, Lactococcus lactis, Oral vaccine, Enterovirus 71

\begin{abstract}
This is an Open Access article that uses a fund-ing model which does not charge readers or their institutions for access and distributed under the terms of the Creative Commons Attribution License (http://creativecommons.org/licenses/by/4.0) and the Budapest Open Access Initiative (http://www.budapestopenaccessinitiative.org/read), which permit unrestricted use, distribution, and reproduction in any medium, provided the original work is properly credited.

Tropical Journal of Pharmaceutical Research is indexed by Science Citation Index (SciSearch), Scopus, International Pharmaceutical Abstract, Chemical Abstracts, Embase, Index Copernicus, EBSCO, African Index Medicus, JournalSeek, Journal Citation Reports/Science Edition, Directory of Open Access Journals (DOAJ), African Journal Online, Bioline International, Open-J-Gate and Pharmacy Abstracts
\end{abstract}

\section{INTRODUCTION}

Enterovirus 71 (EV71) and coxsackievirus A16 (CVA16) are the main pathogens that hand-footcause and-mouth disease (HFMD) [1-4]. A small number of children may present severe symptoms such as aseptic meningitis and acute flaccid paralysis $[5,6]$. With the use of vaccines against EV71, the level of severe HFMD caused by EV71 is decreased in children [7,8]. However, there are still no available clinical vaccines for CVA16. Inactivated vaccine, the most frequently used type of vaccine, has been used against EV71 in the clinics [9]. However, inactivated vaccines are associated with some disadvantages, one of which is that their immune 
effect is not sustainable, thereby necessitating multiple injections. Research has shown that the complex of EV71 and CVA16 VLPS stimulates the production of bivalent antibodies [10]. However, there are reports showing that infants exhibited discomfort due to pain after they were vaccinated through injection [11].

Expectations are high for the development of a vaccine that can exist in the body for a long time, with continuous production of antibodies without any adverse effects. Lactic acid bacteria are used as safe and food-grade bacteria, and as carriers for oral vaccines [12]. The lactic acid bacteria expression system, being an advanced prokaryotic expression system, has some advantages. In the first place, it is safe because lactic acid bacteria are often used as food. Secondly, the level of protein expressed by lactic acid bacteria is low, implying that it is easy to purify the exogenous proteins. Moreover, lactic acid bacteria-based oral vaccine is administered through gastrointestinal mucosa antigen presentation, and can induce the production of an effective immune response [13].

In this study, an oral vaccine against CVA16 was developed by constructing a recombinant Lactococcus lactis that expressed VP1 from CVA16. The results suggest that the oral vaccine induced antibodies against CVA16 via intestinal mucosal immunity.

\section{EXPERIMENTAL}

\section{Cells, virus, vectors and reagents}

Rhabdomyoma (RD) cells purchased from ATCC were cultured in DMEM supplemented with $10 \%$ FBS and antibiotics. The CVA16-GZ08 strain (GenBank accession no. FJ198212) was obtained from Guangzhou Medical University. The CVA16 was titrated to obtain TCID50, arising from typical cytopathic effect (CPE) due to viruses. Plasmid pNZ8148, as well as competent cell line MC1061 and Lactococcus lactis NZ9000 which expresses exogenous proteins, were obtained from Nanjing Zoonbio Biotechnology Co. Ltd, while MRS broth and MRS solid medium were purchased from Guangdong Huankai Microbial Sci and Tech Co. Ltd. TKARA BIO Inc. was the source of DNA Marker and Taq DNA Polymerase.

Protein marker was bought from TransGen Biotech. The restriction enzymes $\mathrm{Ncol}$ and $\mathrm{Xbal}$ were purchased from New England Biolabs, while anti-coxsackievirus A16 antibody was product of Jianglai Biotechnology Co. Ltd. Construction of the plasmid, PNZ8148-
CVA16VP1

The complete gene for CVA16 VP1 (GenBank accession number JF420555.1) was synthesized by Sangon Biotech (Shanghai) Co. Ltd. The sequences of the restriction enzymes $\mathrm{NcOl}$ and $X$ bal were designed to the $5^{\prime}$ ends of the upstream and downstream primers. The initiation codon ATG and the termination codon TTA were designed to be behind the restriction site of the upstream and downstream primers, respectively. The primer sequences are displayed as follows:

CVA16 VP1 forward primer: 5'CCATGGATGGGGATCCTATTGCAGATATGATT GA-3'

CVA16 VP1 reverse primer: 5'TCTAGATTACAACGTTGTTATCTTGTCTCTACT A-3'

To obtain CVA16 VP1 that contained the sequences of the restriction enzymes $\mathrm{NcOl}$ and Xbal, CVA16 VP1 forward and reverse primers were used to amplify the fragment of CVA16 VP1 with Bio-Rad PCR instrument (USA). Polymerase chain reaction was carried out at $94^{\circ} \mathrm{C}$ for $4 \mathrm{~min}$, with 30 cycles of amplification $\left(94^{\circ} \mathrm{C}\right.$ for $30 \mathrm{sec}$, $58{ }^{\circ} \mathrm{C}$ for $30 \mathrm{sec}$, and $72{ }^{\circ} \mathrm{C}$ for $60 \mathrm{sec}$ ); and 72 ${ }^{\circ} \mathrm{C}$ for $160 \mathrm{sec}$ after the last cycle. The PCR fragment was purified using a DNA fragment purification Kit Ver.4.0 (TAKARA BIO Inc.). After purification, the DNA fragment and the plasmid pNZ8148 were digested overnight at $37^{\circ} \mathrm{C}$ with the restriction enzymes $\mathrm{NcOl}$ and $\mathrm{Xbal}$ (New England Biolabs Ltd). The digested DNA fragment and plasmid were purified using the DNA fragment purification Kit Ver.4.0. Nucleic acid concentration was measured with Nano Drop One/one C (Thermo Scientific Ltd). The digested CVA16 VP1 fragment and plasmid (3:1 molar ratio), and $1 \mu \mathrm{l}$ of T4 DNA Ligase (NEB) and $1 \mu \mathrm{l}$ of 10xT4 DNA Ligase Reaction Buffer (NEB) were added. Ultra-pure water was added to bring the reaction volume to $10 \mu \mathrm{l}$, and the solution was mixed and incubated at $16^{\circ} \mathrm{C}$ overnight. Thereafter, the linked products were transferred to E. coli MC1061-competent cells for amplification. Positive clones were picked for sequencing. The match sequence plasmid (named pNZ8148-CVA16 VP1) was kept frozen at $-80{ }^{\circ} \mathrm{C}$ prior to use.

\section{Construction of the expression CVA16 VP1 of NZ9000}

To obtain Lactococcus lactis-competent state of NZ9000, a single colony was picked, inoculated in $5 \mathrm{ml}$ of $\mathrm{GM}$ medium, and incubated at $30^{\circ} \mathrm{C}$ 
overnight. Then, $5 \mathrm{ml} \mathrm{NZ9000} \mathrm{was} \mathrm{transferred} \mathrm{to}$ $50 \mathrm{ml}$ GSGM17 medium at $30{ }^{\circ} \mathrm{C}$ overnight. Next, $5 \mathrm{ml} \mathrm{NZ9000} \mathrm{was} \mathrm{transferred} \mathrm{to} 400 \mathrm{ml}$ GSGM17 medium, incubated at $30{ }^{\circ} \mathrm{C}$ to an absorbance of $0.2-0.3$ at a wavelength of 600 $\mathrm{nm}$, and centrifuged at $4{ }^{\circ} \mathrm{C}$ and $4000 \mathrm{rpm}$ for 20 $\mathrm{min}$. The cells were collected and washed with $400 \mathrm{ml}$ of solution I. Then, $100 \mathrm{ml}$ of solution II was added, vortexed and allowed to stand for 15 min on ice, before it was centrifuged for $20 \mathrm{~min}$ at $4000 \mathrm{rpm}$ at $20^{\circ} \mathrm{C}$. The cells were collected and washed with $100 \mathrm{ml}$ of solution I, suspended in 4 $\mathrm{ml}$ of solution I, dispensed into aliquots of $40 \mu \mathrm{l}$ per tube, and kept frozen at $-80^{\circ} \mathrm{C}$.

The plasmid pNZ8148-CVA16 VP1 and $40 \mu$ of competent cells were mixed, transferred to a $0.2-$ $\mathrm{cm}$ electro-conversion cup in an ice bath, and subjected to electro-transformation at $2000 \mathrm{~V}, 25$ $\mu \mathrm{F}$, and $200 \Omega$. Thereafter, $1 \mathrm{ml}$ of GMMC was immediately added to the electro-conversion cup and transferred into a $1.5-\mathrm{ml}$ tube. Then, the samples were placed in an ice bath for $5 \mathrm{~min}$ and incubated at $30{ }^{\circ} \mathrm{C}$ for $1-1.5 \mathrm{~h}$. Conversion bacteria were coated onto the GM culture board containing chloramphenicol. Next, $10 \mu \mathrm{l}, 100 \mu \mathrm{l}$, and $900 \mu \mathrm{l}$ were separately added to the plate and cultured at $30^{\circ} \mathrm{C}$ for $40 \mathrm{~h}$.

A single colony was introduced into $5 \mathrm{ml}$ of $\mathrm{GM}$ medium at $30^{\circ} \mathrm{C}$ overnight. The plasmid was extracted and identified with PCR using Bio-Rad PCR instrument (USA). The forward primer was 8148-VF1:5'-ACGCGAGCATAATAAACGG-3', while the reverse primer was 8148-VR1:5'CGAAAGCGAAATCAAACGA-3'. Polymerase chain reaction was carried out at $94{ }^{\circ} \mathrm{C}$ for $5 \mathrm{~min}$, with 30 amplification runs, and $72{ }^{\circ} \mathrm{C}$ for $10 \mathrm{~min}$ after the last run.

\section{Western blot assay for protein expressions}

The recombinant Lactococcus lactis NZ9000pNZ8148-CVA16 VP1 cells were cultured in a medium containing $10 \mu \mathrm{g} / \mathrm{ml}$ chloramphenicol at $30{ }^{\circ} \mathrm{C}$ for $8-10 \mathrm{~h}$ in the presence of glucose $(0.5$ $\%$ ). Dilution was carried out to achieve an absorbance value of 0.4 . Then, nisin was separately added to the remaining cultures to a final concentration of $50 \mathrm{ng} / \mathrm{ml}$ or $100 \mathrm{ng} / \mathrm{ml}$, and cultured overnight at $30^{\circ} \mathrm{C}$ for $4 \mathrm{~h}$ to induce expression of fusion protein. After induction, the cells were subjected to SDS-polyacrylamide gel electrophoresis. Western blot assay was done as outlined previously to identify the expression of the CVA16 VP1 protein, using monoclonal antibody CVA16 IgG (Jianglai Biotechnology Co. Ltd, 1:1000) as $1^{0}$ antibody, and horse radish peroxidase-linked secondary antibody.

\section{Oral vaccination}

In all, ten 6-week-old BALB/c female mice were bought from Guangdong Medical Laboratory Animal Centre and fed in an IVC squirrel cage. They were assigned to 2 groups: pNZ8148CVA16 VP1 and pNZ8148-vector groups, each with 5 animals. Mice in pNZ8148-CVA16VP1 group and pNZ8148-vector group were subjected to oral vaccination using recombinant Lactococcus lactis NZ9000-pNZ8148-CVA16VP1 and Lactococcus lactis NZ9000-pNZ8148, respectively, at a dose of $5 \times 10^{11} \mathrm{CFU} / \mathrm{ml}$ in 500 $\mu \mathrm{l} 3$ times a day. The mice were vaccinated on days $1,3,5,7,14,21,28$ and 35 . After 35 days, all mice were sacrificed, and serum and nasal lavage samples were obtained.

\section{ELISA}

Titres of $\lg A$ were determined in serum and nasal lavage using enzyme-linked immunosorbent assay (ELISA) [14]. A 96-well enzyme plate was coated with purified CVA16 virus $\left(10^{7} \mathrm{TCID} 50 / \mathrm{ml}\right)$, and $50 \mu \mathrm{l} /$ well was added. Then, the plate was incubated at $4{ }^{\circ} \mathrm{C}$ for $12 \mathrm{~h}$. Thereafter, horse radish peroxidase-linked antimouse IgG (for serum) or IgA (for nasal lavage) diluted 1: 8000 or 1: 10000 , respectfully, was used in mice as $2^{0}$ antibody for determination of the levels of antibodies against CVA16.

\section{In vitro test for CVA16-neutralizing antibodies}

Mouse sera were subjected to incubation for $1 / 2 \mathrm{~h}$ at $56{ }^{\circ} \mathrm{C}$ before the test, and were diluted $1: 2$. Then, $50 \mathrm{ml}$ of each serum was added to $50 \mathrm{~mL}$ of 100 TCID $_{50}$ of virus, followed by incubation at $37{ }^{\circ} \mathrm{C}$ for $1 \mathrm{~h}$ and adsorption onto 96-well microtiter plates pre-seeded with RD cells. The plates were incubated at $37^{\circ} \mathrm{C}$ for $48 \mathrm{~h}$, followed by titre reading in terms of the highest dilution that suppressed viral multiplication.

\section{Statistical analysis}

Differences between two groups were analysed using Student's $t$-test. Statistical analysis was done using SPSS 16.0 (IBM). Values of $p<0.05$ were taken as indicative of statistically significant differences.

\section{RESULTS}

The CVA16 gene was cloned into the pNZ8148 plasmid. Then, the plasmid pNZ8148-CVA16VP1 was transformed into NZ9000 Lactococcus lactis bacteria. The primer pair 8148-VF1 and 8148VR1 were used to detect positive clones of the Lactococcus lactis NZ9000 containing the 
plasmid pNZ8148-CVA16VP1. The fragment was a 1200-bp band, as shown in Figure 1 A. Double digestion with the restriction enzymes $\mathrm{Ncol}$ and Xbal produced a small 800-bp band, as shown in Figure $1 \mathrm{~B}$.
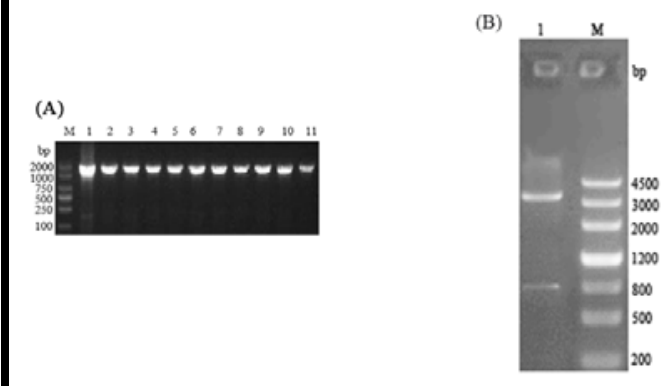

Figure 1: Map of nucleic acid electropherogram. Map of recombinant Lactobacillus plasmid PCR nucleic acid electropherogram. M: DNA marker (down to up: $100,250,500,750,1000$ and $2000 \mathrm{bp}$ ); 1: plasmid of PNZ8148-CVA16 VP1 as the template; 2 to 11: plasmid of extraction from bacterial fluid; Map of recombinant Lactobacillus plasmid enzyme digestion nucleic acid electropherogram. M: DNA marker (down to up: $200,500,800,1200,2000$ and $3000,4500 \mathrm{bp}$ ) 1: plasmid of pNZ8148-CVA16 VP1 which served as the enzyme digestion template

\section{Expression of CVA16 antigen and identification by Western blotting}

The positive clones were picked for induction with different concentrations of nisin for $4 \mathrm{~h}$ and overnight. Figures $2 \mathrm{~A}$ and $2 \mathrm{~B}$ show the SDSPAGE results of NZ9000-pNZ8148-CVA16VP1 after nisin induction. The results indicate that NZ9000-pNZ8148-CVA16-VP1 was expressed at $35 \mathrm{kDa}$, the molecular weight of the CAV16-VP1 protein band. The broken supernatant of the positive strain that was not induced was the control. The protein bands were not obvious between induction samples and non-induction samples.

The results of Western blotting are shown in Figures $2 \mathrm{C}$ and $2 \mathrm{D}$. The broken supernatant and sediment that were induced by two concentrations of nisin for $4 \mathrm{~h}$ showed immunoreactive protein bands of $35 \mathrm{kDa}$. Moreover, there were no inductions of target proteins overnight by nisin at doses of $50 \mathrm{ng} / \mathrm{ml}$ or $100 \mathrm{ng} / \mathrm{ml}$.

\section{pNZ8148-CVA16VP1 induced CVA16-specific antibody response via oral vaccination}

The CVA16-specific IgG antibody was induced in sera of mice orally given NZ9000-pNZ8148CVA16-VP1 (Figure 3A). In addition, IgA titre in nasal lavage was detected in mice orally fed NZ9000-pNZ8148-CVA16-VP1, as shown in
Figure 3B. As expected, $\lg G$ in sera and $\lg A$ in nasal lavage were absent in the control group mice. There was statistically difference in CVA16-specific IgG antibody level between the NZ9000-pNZ8148-CVA16-VP1 group (0.49 \pm $0.05)$ and control group $(0.05 \pm 0)$ when the antiserum was diluted $1: 10(t=19.84 ; p<0.05)$. In addition, there was statistically significant difference in CVA16-specific IgA antibody level between the NZ9000-pNZ8148-CVA16-VP1 group $(0.17 \pm 0.02)$ and control group $(0.05 \pm 0)$ at antiserum dilution 1:10 ( $t=12.08 ; p<0.05)$.

To test the neutralization titre of antisera of oral vaccine against CVA16, mice anti sera raised against CVA16 were subjected to in in vitro microneutralization test, with RD cells infected with $100 \mathrm{TCID}_{50}$ of CVA16. The RD cells were completely protected from CPE by antiserum from mice subjected to whole-virion immunization at a neutralization titre of $1: 16$. This result is shown in Figure 3C.

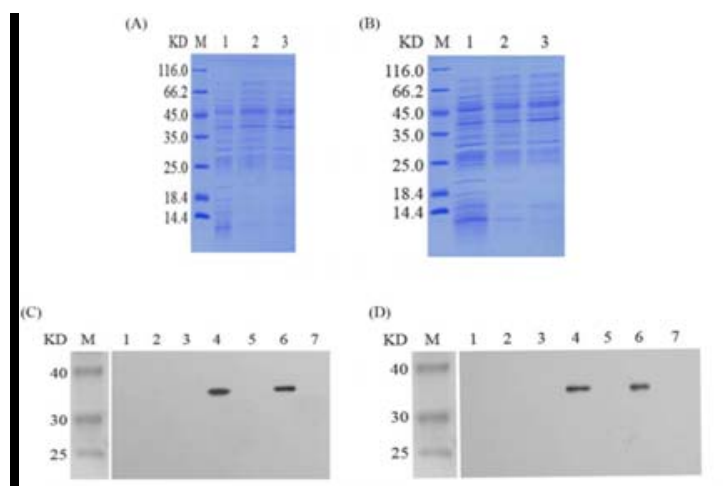

Figure 2: SDS-PAGE result for expression of CVA16 VP1

\section{DISCUSSION}

Lactic acid bacteria, as probiotics, settle securely on the intestinal tract surface, which is highly beneficial to the body. Some studies on the expression of alien proteins in L. lactis showed that it could be a versatile expression system and delivery vehicle for various proteins. Many oral vaccines have been made with lactic acid bacteria. These include protected rotavirus vaccine [15], porcine epidemic diarrhoea virus oral vaccine [16], and human papillomavirus type 16 vaccine [17]. Foreign proteins expressed by lactic acid bacteria direct stimulation of the intestine to produce immunity. In this study, the VP1 protein of CVA16 was expressed in cells. However, a signal peptide and optimized expression conditions were added. This protein may have higher merit than other secreted expression proteins. 

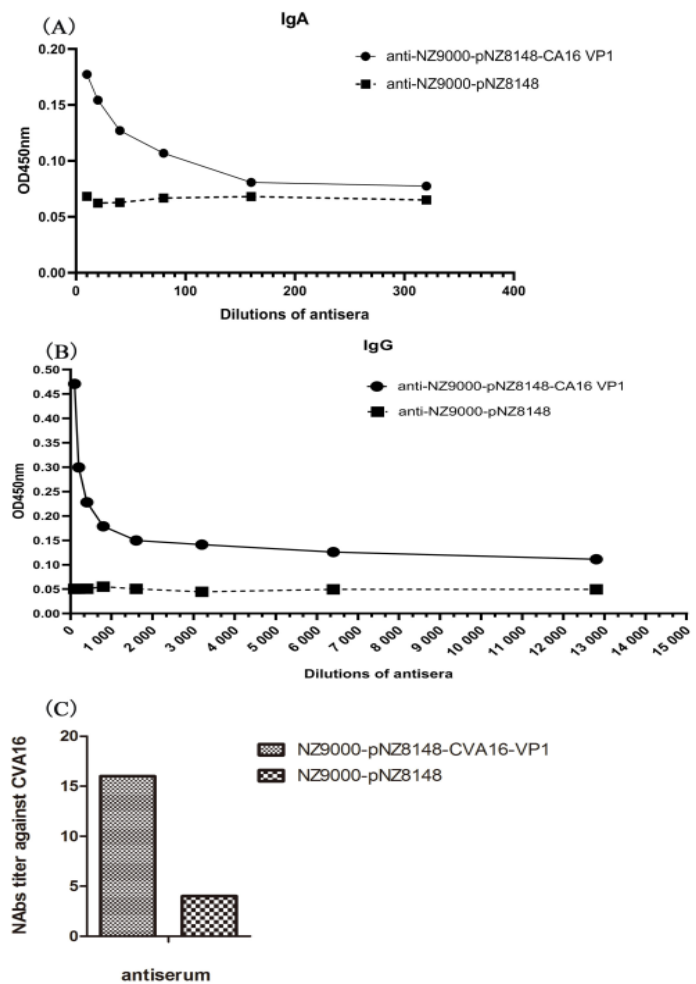

Figure 3: CVA16-VP1-specific antibody responses in mice with oral vaccination of NZ9000-pNZ8148CVA16-VP1

The lactic acid bacteria that secrete expression proteins need to constantly express proteins to stimulate the intestine. Therefore, the concentration of expression protein may be low. In contrast, foreign protein is constantly expressed intracellularly until the bacteria are degraded.

In addition to inducing the body to produce IgG antibodies, lactic acid bacteria stimulate the production of $\lg \mathrm{A}$ antibodies. In the anti-HPV field, researchers constructed recombinant strains of Lactococcus lactis NZ9000 that express HPV E6 protein which could be used to treat HPV-16 associated with cervical cancer.

However, there are two problems with oral vaccines made by lactic acid bacteria, one of which involves stomach acid. Research has shown that overexpressing the recT gene of lactis NZ9000 enhances tolerance of acid stress. In this study, the lactic acid bacterium NZ9000 was used to express CVA16 VP1. Therefore, theoretically, it could withstand the hydrochloric acid effect. The second problem has to do with drug-resistant genes in recombination-prone lactic acid bacteria. The main factor in this problem originates from lactic acid bacterial expression plasmid. With advances in biotechnology, non-resistant plasmids have been used to express foreign proteins, but it is difficult to screen positive bacteria.

Tetracyclines have some desirable attributes that make them suitable as antibiotics: they are active against gram +ve and gram-ve microorganisms, and they are associated with safety and tolerability by patients. Moreover, tetracyclines are available in intravenous (IV) and oral dosage forms. The pNZ8148 plasmid has an antichloramphenicol gene which leads to chloramphenicol resistance. Chloramphenicol has been widely used in the treatment of various sensitive bacterial infections, with serious adverse reactions in the haematopoietic system. Thus, its clinical application has been strictly controlled. Therefore, there is no need to worry about this problem.

\section{CONCLUSION}

An oral CVA16 vaccine made from Lactobacillus elicited protective antibodies against CVA16. Thus, it has a potential for use as an oral vaccine against CVA16; however, further investigations, including animal trials, are required to ascertain its suitability.

\section{DECLARATIONS}

\section{Acknowledgement}

This work was supported by the Dongguan Bureau of Science and Technology for the City Key Programmes of Science and Technology (project nos. 2015108101020, 2018507150 1001618, 2016108101029 and 2017507150 100444). The funders played important roles in the study design, data collection and analysis, decision to publish, and preparation of the manuscript.

\section{Conflict of interest}

No conflict of interest is associated with this work.

\section{Contribution of authors}

We declare that this work was done by the author(s) named in this article and all liabilities pertaining to claims relating to the content of this article will be borne by the authors. All authors read and approved the manuscript for publication. Zaixue Jiang performed most experiments and took part in drafting the manuscript. Xingui Tian designed the work, analysed the data and participated in drafting the 
manuscript. Xiaomei Lu helped analyse the data. Baimao Zhong designed and supervised the work, and edited the final version of the manuscript. All authors read and approved the final version of the manuscript.

\section{Open Access}

This is an Open Access article that uses a funding model which does not charge readers or their institutions for access and distributed under the terms of the Creative Commons Attribution License (http://creativecommons.org/licenses/by/ 4.0) and the Budapest Open Access Initiative (http://www.budapestopenaccessinitiative.org/rea d), which permit unrestricted use, distribution, and reproduction in any medium, provided the original work is properly credited.

\section{REFERENCES}

1. Mei L, Song $X$, Kong $Y, Y u$ G. An assessment of a pediatric early warning system score in severe handfoot-and-mouth disease children: To detect clinical deterioration in hospitalized children. Medicine (Baltimore) 2018; 97(26): 11355.

2. Esposito S, Principi N. Hand, foot and mouth disease: current knowledge on clinical manifestations, epidemiology, aetiology and prevention. Eur J Clin Microbiol Infect Dis 2018; 37(3): 391-398.

3. Zhao $Y$, Zhang H, Liu H, Zhang J, He L, Sun H, Huang $X$, Yang Z, Ma S. Molecular characteristics of hand, foot, and mouth disease for hospitalized pediatric patients in Yunnan, China. Medicine (Baltimore) 2018; 97(31): 11610.

4. Owatanapanich S, Wutthanarungsan R, Jaksupa W, Thisyakorn U. Risk Factors for Severe Enteroviral Infections in Children. J Med Assoc Thai 2016; 99(3): 322-330.

5. Lee $K Y$. Enterovirus 71 infection and neurological complications. Korean J Pediatr 2016; 59(10): 395-401.

6. Mao Q, Wang Y, Yao X, Bian L, Wu X, Xu M, Liang Z. Coxsackievirus A16: epidemiology, diagnosis, and vaccine. Hum Vaccin Immunother 2014; 10(2): 360-367.

7. Zhuang ZC, Kou ZQ, Bai YJ, Cong X, Wang LH, Li C, Zhao L, YU XJ, Wang ZY, Wen HL. Epidemiological Research on Hand, Foot, and Mouth Disease in Mainland China. Viruses 2015; 7(12): 6400-6411.
8. Mao QY, Wang Y, Bian L, Xu M, Liang Z. EV71 vaccine, a new tool to control outbreaks of hand, foot and mouth disease (HFMD). Expert Rev Vaccines 2016; 15(5): 599-606.

9. Hu Y, Zeng G, Chu K, Zhang J, Han W, Zhang Y, Li J, Zhu F. Five-year immunity persistence following immunization with inactivated enterovirus 71 type (EV71) vaccine in healthy children: $A$ further observation. Hum Vaccin Immunother 2018; 14(6): 1517-1523.

10. Ku Z, Liu Q, Ye $X$, Cai $Y$, Wang $X$, Shi J, Li D, Jin $X$, An $W$, Huang $Z$. A virus-like particle based bivalent vaccine confers dual protection against enterovirus 71 and coxsackievirus A16 infections in mice. Vaccine 2014; 32(34): 4296-4303.

11. Huda MN, Ahmad SM, Alam MJ, Khanam A, Afsar MNA, Wagatsuma $Y$, Raqib $R$, Stephensen $C B$, Laugero $K D$. Infant cortisol stress-response is associated with thymic function and vaccine response. Stress 2018; 22(1): 36 43.

12. Yurina V. Live Bacterial Vectors-A Promising DNA Vaccine Delivery System. Med Sci (Basel) 2018; 6(2): 27.

13. de Castro $C P$, Drumond MM, Batista VL, Nunes A, Mancha-Agresti $P$, Azevedo V. Vector Development Timeline for Mucosal Vaccination and Treatment of Disease Using Lactococcus lactis and Design Approaches of Next Generation Food Grade Plasmids. Front Microbiol 2018; 9: 1805.

14. Monedero V, Rodríguez-Díaz J, Viana R, Buesa J, Pérez-Martínez G. Selection of single-chain antibodies against the VP8* subunit of rotavirus VP4 outer capsid protein and their expression in Lactobacillus casei. Appl Environ Microbiol 2004; 70(11): 6936-6939.

15. Liu DQ, Ge JW, Qiao XY, Jiang YP, Liu SM, Li YJ. Highlevel mucosal and systemic immune responses induced by oral administration with Lactobacillus-expressed porcine epidemic diarrhea virus (PEDV) S1 region combined with Lactobacillus-expressed N protein. Appl Microbiol Biotechnol 2012; 93(6): 2437-2446.

16. Taghinezhad-S S, Mohseni AH, Keyvani H, Razavilar V. Protection against human papillomavirus type 16induced tumors in C57BL/6 mice by mucosal vaccination with Lactococcus lactis NZ9000 expressing E6 oncoprotein. Microb Pathog 2019; 126: 149-156.

17. Zhu Z, Ji X, Wu Z, Zhang J, Du G. Improved acid-stress tolerance of Lactococcus lactis NZ9000 and Escherichia coli BL21 by overexpression of the anti-acid component recT. J Ind Microbiol Biotechnol 2018; 45(12): 1091 1101. 